\title{
CONCEPT AND MODEL OF SHARIA SALONS AND SPAS: MYTH OR REALITY?
}

\author{
Bafadhal Aniesa Samira*, Yulianto Edy, Siswidiyanto, \\ Hendrawan Muhammad Rosyihan \\ Business Administration Department, Faculty of Administrative Science, \\ University of Brawijaya, Indonesia \\ *E-mail: aniesa.bafadhal@ub.ac.id
}

\begin{abstract}
Currently, health issues have grown rapidly into Health Tourism segment to strengthen Indonesia's tourism. Ironically, the proliferation of salon and spa business as well as other forms of health tourism business is considered to cause negative effects in the form of destructive cultural penetration of foreign tourists. This study aimed to analyze the prospects of sharia salons and spas in safeguarding the health tourism in Indonesia. Furthermore, we examine the mix variables of sharia marketing as a marketing stimulus to encourage Muslim tourists in making the decision to visit and re-visit as well as their interest in the sharia salons and spas. This explanatory study uses the paradigm of quantitative research involved 13 informants of Muslim owner/staff sharia salons and spas in East Java, Indonesia. The results of this study indicate that stimulus of sharia marketing is needed to develop tourist visits, especially Muslim travelers in health tourism destination of sharia salons and spas.
\end{abstract}

\section{KEY WORDS}

Health tourism, sharia, salons, spas, Indonesia.

Thousands of years ago, people had to travel to distant places in order to heal themselves, so essentially a medical tourism is a phenomenon that has long existed. In its development, global competition has emerged in the health care industry. Countries that have advanced the tourism, such as Switzerland, Germany, France, UK, USA, Canada, Austria, Australia, Japan, China, Singapore, and even Malaysia have long organized forms of such health tourism for both domestic tourists and foreign tourists. This then led to the term of borderless patient for health tourists in developed countries and in developing countries. Wealthy patients from developing countries have long traveled to the developed countries for high-quality medical care. However, now many middle economic class patients from developed countries travel to developing countries to seek high quality medical care at affordable prices (Herrick, 2007).

Currently, health issues have grown rapidly into Health Tourism segment to strengthen tourism, not least for Indonesia, which has a lot of local knowledge in the field of health from the science of alternative medicine heritage. Health tourism activity generally refers to patients who travel for beauty, rehabilitation, care of themselves in their recreation. Health tourism emerged as a new form for the tourism industry which is diffusion between the needs of an individual to obtain health care and their wish to travel in the same time (Rollyson, 2010; Munro, 2012; Snyder et al., 2013; Henema, 2014). The form of implementation of health tourism includes yoga, gym or fitness, dentistry, spiritual festivals, ayurveda, mud baths, cosmetic surgery, acupuncture and acupressure, and what has been popular in Indonesia is a salon and spa services business.

Tilaar (2011) state that the development of salon and spa in Indonesia and the world is growing rapidly. Factors causing the inner pressure or stress are increasingly high that many people, especially among metropolitan, require salon and spa as a means of treatment for relaxing theraphy. Ironically, the development of health tourism in Indonesia also poses the threat of penetration of "wild west" (Macready, 2007; Cortez, 2008; Johnston et al, 2010) brought by foreign tourists as foreign culture can lead to transformation of culture or even cultural amnesia, that will ultimately bring multiple effects on various sectors of public life and business industry. 
Young (1973) suggests that tourism may give rise to an undesirable activity, such as prostitution, sex trafficking, and HIV and penetration of foreign culture that can have negative impacts for local communities. In public perception, spa and salon business is identical to the negative stigma (Narendran, 2011). This is evidenced by the emergence of 'plus-plus' salon and spa, erotic massage parlors, homosexual salon as well as prostitution under the guise of health and fitness business in Indonesia. Although it promotes itself as a spa and sauna with exclusive prices and services, in practice it is similar to prostitution and other hedonism.

The mindset of tourism businesses people tend to be oriented to economic advantages alone without strong commitment and awareness in maintaining cultural, social, and religious values; and this can be a threat to the nation and especially for the development of the tourism industry itself. On the other hand, Indonesia is a potential market of abundance domestic Muslim tourists. However, the limited variety of facilities and infrastructure of the health tourism and ethical fulfillment of sharia and affluence of 'plus-plus' spa and salon in Indonesia shows that the country is still weak in capturing the opportunities and potential of Muslim tourists even for domestic market needs.

On a variety of spa and salon areas in Indonesia, it is difficult to obtain standard service according to the value of sharia for Muslim women who keep the "aurat" according to the religious beliefs, for example in terms of a therapist of the same sex, no-pork raw materials, no eyebrow shaving or like-man hair, and so forth.

Recognizing the potential and opportunities of Muslim tourists, and keeping the noble values of the nation's culture as well as maintaining and increasing attraction for them, both domestic and foreign tourists, on health tourism in Indonesia, the Ministry of Tourism and Creative Economy has started to promote standardization of sharia spa and salon (Ministry of Tourism, 2015).

Sharia salons and spas is a model of spas and salons that offer beauty therapist and rooms based on gender, halal cosmetic materials as well as service, interior, equipment and other facilities that comply with Islamic law (Yemen et al., 2012). Sharia salons and spas is expected to minimize the practice of adultery and other hedonism. Sharia salons and spas business continues to grow and is proven profitable and some has been using a franchise system. Until now, there are about less than a hundred sharia salons and spas in Indonesia. So far, the Majelis Ulama Indonesia (MUI) has not issued a special fatwa and sharia certification for the operation of sharia salons and spas, but many spas and salons are getting halal certification for its products.

Malang is a city in the province of East Java, Indonesia, which has a high potential to develop health tourism, especially with the support of domestic Muslim tourists. The high number of students, especially Muslim ones, poses potential for tourism in Malang City, Surabaya City and Sidoarjo City, East Java, Indonesia. They need to be accommodated and facilitated for health and fitness that meet the values and ethics of sharia, one of which is through sharia spas and salons. Furthermore, in the operation of sharia spa and salon, evaluation and assessment of the effectiveness of marketing and management variables is important to increase the number of users and encourage repeat visits, to increase the income of business, and to help develop the health tourism in Indonesia.

This study attempts to improve the health tourism segments through prospective sharia spas and salons in Malang, in encouraging domestic Muslim tourists. This study aimed to analyze the effect of implementation of sharia services marketing mix that has been applied to decision buying as well as revisit intention in sharia salons and spas.

Originality that this research offers is that it fills the gap of research on prospective sharia salons and spas in extending health tourism using a sharia marketing perspective that is still missing in Indonesia. Abroad, there are only a few researchers like Yemen et al. (2012) in Malaysia, conduct the same study. In Indonesia, previous research on sharia spas and salons is still in early stages of analyzing phenomena and behavior, in a study by Budiyanto (2015). While other researchers analyze the sharia salon spa business from various perspectives such as from the perspective of Islamic architecture in a study by Kusjuniardi (2014), Trison (2015), and Indry (2014) as well as from the perspective of human resource management, for example in research by Sari (2013). 


\section{LITERATURE REVIEW}

Health Tourism. According to Pendit (1994), there are several types of tourism already known, such as Health Tourism, i.e. one's journey with the aim to exchange the circumstances and the environment in one's everyday live for the sake physical and spiritual health.

Health tourism is a blend of Medical Tourism and Wellness Tourism. Wellness or Healthy Lifestyle Tourism provides improved and preventive health services, and puts more emphasis on relaxation and good look, like beauty, weight loss, and fitness services. Medical tourism provides conventional and traditional medical services such as cosmetic surgery, organ transplantation, chemotherapy, physiotherapy, massage, and acupuncture.

Sharia Marketing. Alom and Haque (2011) state that sharia marketing can be defined as a process and strategy (hikmah) to meet the need through the halal products and services (tayyibat) by mutual consent and welfare (Falah) of both parties of buyer and seller to achieve material and the spiritual wealth in the world and the hereafter.

Sharia Salon and Spa. Sharia salons and spas are currently experiencing exponential and massive growth. This is similar and becomes the more popular development of modern Islamic hammam, which has long been growing, especially in the Umayyads. Nevertheless, at present, research on sharia salons and spasshows such poor trendas few researchers pay attention to the potential of innovation of sharia salons and spas compared conventional salons and spas especially in Muslim countries. Some researchers have initiated research on salons and spas in various countries, among others such as Malaysia (Bahaudin and Abdullah, 2010; Husain and Jamal, 2015), Indonesia (Bafadhal, 2017), Thailand (Chookaew et al., 2015), and Finland (Islam and Kärkkäinen, 2013). Even so, those researchers have put an important springboard for the development of the concept of sharia salons and spas.

Spa was originally defined as a medical treatment to ensure total relaxation for those who receive treatment using water vapor as its main element. Clark (in Bahanudin and Abdullah, 2010) shows that spas can be divided into four types, namely retreat spas, resort spas, day spas and salons or mini spas. Callen (2007) claims that in their development, spas are no longer just associated with mineral springs and therapeutic use of water. Spas now present in the form of chic services and products in a beauty salon, are available in a variety of department stores, and may also involve place to eat delicious and healthy food or even become the ultimate destination for a vacation.

It is similar to the development of services in the Islamic hammam as a forerunner of sharia salons and spas, as it also provided services such as guard baths (hammamīān), barber (salmānīān), masseur (āsījānān), therapists or cuppers (hajjāmān), and others (Mez, 1992). Islamic Practices Spa provides spa services, beauty therapists based on sex, the use of differentrooms and different services for male and female clients, and services in accordance with Islamic law (Yemen et al., 2012). By applying Islamic values in the beauty business, it will realize Muslim needs to feel comfortable and relaxed, knowing that servicesfor men and women are separated so privacy is maintained.

\section{METHODS OF RESEARCH}

This explanatory research uses qualitative research paradigm. The sample in this study was 13 owner/staff of sharia salons and spas in Malang City, Surabaya City and Sidoarjo City East Java, Indonesia. The data was collected for approximately 2 month from July 2017 until August 2017.

This research was conducted by distributing questionnaires to domestic Muslim tourists as visitors the sharia salons and spas in Malang City, Surabaya City and Sidoarjo City East Java, Indonesia. Respondents were identified based on informant name, informant position, age of company, business types, especially for woman, non-Muslims as seen as Table 1 below. Qualitative analysis technique such as interview and literature study was used in this study. 
Table 1 - Description of Informants

\begin{tabular}{|c|c|c|c|c|c|c|}
\hline No & Area & Company Name & Age of Company & Business Types & Esp. for Woman & Esp. for Non-Muslim \\
\hline 1 & SBY & Alesya & 9 years & Private & Yes & Yes \\
\hline 2 & SBY & Alfafa & 4 years & Private & Yes & Yes \\
\hline 3 & SBY & Noura & 6 years & Private & Yes & No \\
\hline 4 & SBY & Nayyara & 7 years & Private & Yes & No \\
\hline 5 & SBY & Kayla & 8 years & Private & Yes & Yes \\
\hline 6 & SBY & Deva & 10 years & Private & Yes & Yes \\
\hline 7 & MLG & Fatimah & 13 years & Private & Yes & No \\
\hline 8 & MLG & Almira & 2 years & Private & Yes & No \\
\hline 9 & MLG & D'Mutia & 4 years & Franchise & Yes & Yes \\
\hline 10 & MLG & Yasna & 5 years & Private & Yes & No \\
\hline 11 & SDA & Sholika Yahya & 3 years & Private & Yes & Yes \\
\hline 12 & SDA & Jasmine & 2 years & Private & Yes & Yes \\
\hline 13 & SDA & Dhila Jasmine & 6 years & Private & Yes & Yes \\
\hline
\end{tabular}

\section{RESULTS AND DISCUSSION}

Based on literature study and interview, the author states that sharia salons and spas are a form of business that provides promotive and preventive wellness services and products combining aesthetic, cosmetics, and spiritual treatments of the body, face, hair, and soul for both men and women, especially Muslims in conformity with Islamic law as the main determinant.

Muslim consumers, managers of Muslim-friendly salons and spas as well as the government must coordinate as to play the important role in setting up education and training, regulation, accreditation, quality standards, and marketing of sharia salons and spas. Through a review of various sources, the author has developed a standard concept for sharia salons and spas, i.e. the Salient Traits of Sharia Salon and Spa in table 2 and figure 1.

Tabel 2 - Salient Traits of Sharia Salons and Spas

\begin{tabular}{|c|c|c|}
\hline No. & Category & Salient traits \\
\hline 1 & 2 & 3 \\
\hline \multirow{34}{*}{1} & \multirow{34}{*}{ Services } & Forbidden to shave the eyebrows, beard, facial hair \\
\hline & & Forbidden to do hair coloring with black color, preferred red and yellow color \\
\hline & & Forbidden to show aurat especially the body secara vulgar \\
\hline & & Products must free form haram ingredients \\
\hline & & Forbidden to treat wig and konde \\
\hline & & Therapist must be of the same sex with the clients \\
\hline & & Tersedia layanan mencabut bulu ketiak, dada dan betis \\
\hline & & Suggested (sunnah) to shave the pubic hair and trim the mustache for man but not for woman \\
\hline & & Forbidden to have hair extension \\
\hline & & Suggested to trim the nails (pedicure andmanicure) \\
\hline & & Suggested to have a face mask and gulp down the body with blossom mask or halal materials \\
\hline & & Forbidden to mencukur atau menggundul rambut wanita hanya boleh memotong \\
\hline & & Forbidden to doqoza' (cut some hair and leave some other) \\
\hline & & Women are forbidden to cut all their hair resembling men \\
\hline & & Forbidden to have tattoos \\
\hline & & Forbidden to pull out grey hair \\
\hline & & Allowed to wear nail polish for women during their period \\
\hline & & Forbidden to wear nail polish as it causes wudhu or ablution not perfect form inai \\
\hline & & Allowed massage using oils; the treatment must not evoke lust and not torture the body \\
\hline & & Allowed to use aromatherapy with natural ingredients and non-intoxicating \\
\hline & & Allowed to have mud bath \\
\hline & & Allowed to have spice bath / herb \\
\hline & & Allowed to make the eyes up using kohl; the makeup must be simple \\
\hline & & $\begin{array}{l}\text { Hair and nails of the female clients must be collected when they are having their period during treatment; } \\
\text { the hair and nails must be included during junub bath }\end{array}$ \\
\hline & & Allowed to make up the hands and feet with henna \\
\hline & & Allowed to do dental spa and with siwak \\
\hline & & Allowed to style and to comb the hair \\
\hline & & Allowed to use perfume during treatment \\
\hline & & Allowed to treat acne and boils in particular with dzarirah perfume. \\
\hline & & Braid is allowed, yet konde is prohibited \\
\hline & & Not allowed to bath in warm water pool \\
\hline & & Allowed to use steam shower or sauna dengan ruangan terpisah antar klien \\
\hline & & Allowed to use ice water for treatment \\
\hline & & $\begin{array}{l}\text { Allowed to provide traditional services or modern ones as long as the services are not prohibited by Quran, } \\
\text { Hadith, ljma, and Qiyas }\end{array}$ \\
\hline
\end{tabular}




\begin{tabular}{|c|c|c|}
\hline 1 & 2 & 3 \\
\hline \multirow{10}{*}{2} & \multirow{10}{*}{ Facilities } & Providing the waiting room for the husband or mahram who accompanies the female customers \\
\hline & & Separating the service rooms between male and female \\
\hline & & Reciting of the Al-Quran verses \\
\hline & & The equipment used do not violate Islamic law and is free from any haram materials \\
\hline & & Availability of prayer room, prayer mat, and the Qibla direction \\
\hline & & No music expressing seductive and controversial messages \\
\hline & & Non-figurative decoration pattern (no pictures and statues, figurines of human and animal form) \\
\hline & & Bed, toilets, and therapy room facing Mecca \\
\hline & & Water friendly restroom or toilet \\
\hline & & Build-in wudhu facilities located outside the prayer room \\
\hline \multirow{13}{*}{3} & \multirow{13}{*}{ Management } & Therapists and staffs diutamakan beragama Islam \\
\hline & & Prohibited from providing services that lead to negligence of the prayer time \\
\hline & & Not hiring transgender as the staff \\
\hline & & Therapists and staff wearing descent clothes covering the aurat \\
\hline & & Providing special time for prayers for Muslim workers \\
\hline & & Special arrangement for Muslim workers duringRamadhan \\
\hline & & Ethical marketing and promotion \\
\hline & & Conducting corporate social responsibility \\
\hline & & Paying tax \\
\hline & & Conducting philanthropic donation based on zakat principles, giving infaq and sodaqoh \\
\hline & & All transaction using the network of Islamic financial institution such as sharia banks \\
\hline & & Management and ownership preferably by Muslim individual \\
\hline & & If possible, sharia supervisory boards are available within the organizational structure of the company \\
\hline
\end{tabular}

There are also controversies and conflicts related to halal haram for a woman to open their aurat in front of non-Muslim women. Some scholars declare that this is haram except for emergency and life-threatening conditions such as a medical operation or accident and treatment of diseases. However, when it comes to health care that is not urgent, most scholars agree that Muslim women should not open their aurat in the presence of nonMuslim women. Therefore, it is better that Muslim women go to a salon and spa managed and owned by Muslims. Meanwhile, for non-Muslims interested in opening up a salon and spa targeting Muslim users, they are suggested to provide Muslim therapists and staff. The development of beauty and spa treatments in various countries is because people are looking for new and unique experience. The main problem in dealing with beauty treatments and spa operations from the perspective of Islam is the issue of mahram, aurat, and separation of different sexes.

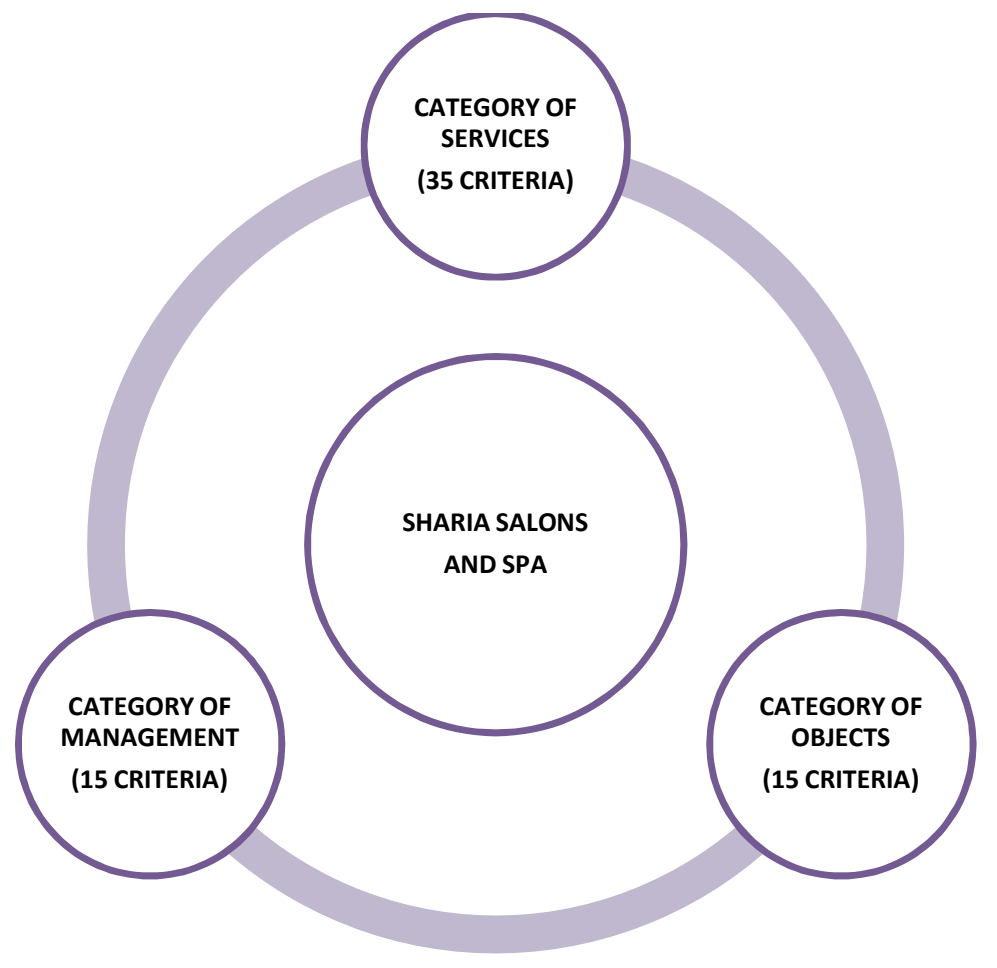

Figure 1 - Standard Model of Sharia Salon and Spa 
The Quran commands, "...and not expose their adornment except to their husbands, their fathers, their husbands' fathers, their sons, their husbands' sons, their brothers, their brothers' sons, their sisters' sons, their women, that which their right hands possess, or those male attendants having no physical desire, or children who are not yet aware of the private aspects of women...." (An-Nur: 31).This shows the prohibition for a Muslim woman to appear without hijab in front of a non-Muslimfemale, fearing that the non-Muslim woman will be able to explain to her husband or other strangers (non-mahram of the Muslim woman) regarding the physical condition of the Muslim woman so as if the man sees the Muslim woman directly. Actually, Muslim women are allowed to get salon and spa treatments, as long as the treatments are not too much and not to show off. Muslim women should keep their beauty only for their husband (or future husband). It is necessary for married Muslim women to ask for husband's permission before going to the salon; the husband must also allow the treatments. It is also important not to miss any prayers during the treatments. The treatments must nottorture the body, such as shaving and embroidering eyebrow, hair extension, and tattoos.

\section{CONCLUSION}

Although Islamic marketing concept is relatively new in comparison with Western marketing, it does not mean that Islam has not been familiar with the marketing concept. Muslims have been trading for over a thousand years, have made contact with the various local cultures, and have adjusted their approach in the context of Islam in order to market their goods and services (Wilson and Grant, 2013). As part of the competitive tourism industry,sharia salons and spas not only provide facilities and products but are also required to execute a sharia marketing strategy to allocate their resources well to increase the number of customers. Although sharia salon and spa business is currently very promising, without sharia marketing management strategy, the value will certainly lose in the competition. In addition, there are differing opinions of managersin the implementation of standard operating procedure of sharia salons and spa. Evaluation and assessment on the effectiveness of sharia marketing management run by managers of sharia spas and salons is necessary in order to increase the number of service users, to increase revenues, and to help develop the health tourism in Indonesia.

The exponential growth of sharia salons and spas marks a positive trend; they have even grown into a franchise business. However, the development of sharia salons and spas in some countries has not been formalized by a fatwa of the authorities. Malaysia has issued a special fatwa on Islamic Spa Practice by Majelis Fatwa Kebangsaan. Indonesia, on the other hand, has not done so. A fatwa is a religious order issued by a leader of a Muslim scholar. As there has been no such fatwa, differences in the implementation of sharia salons and spas exist, both in Indonesia and in various countries around the world. Many salons and spas claim to work on sharia, but they have not uniformly applied Islamic values in both service and management.

Muslim scholars are expected to consider the importance of the fatwa specifically for sharia salons and spas, so the fatwa can be become a technical reference in the implementation of the business in the near future. With the fatwa, sharia salons and spas have standards in meeting the health care needs of domestic and foreign Muslims. In addition, the fatwa must also be reinforced with the regulations of the government legally and obligatory binding all sharia salons and spas.

\section{REFERENCES}

1. Alaika, Ilma Arsala (2014) factor-faktor bauran pemasaran yang berhubungan dengan minat kunjungan ulang pasien RS Hermina Bekasi Tahun 2014, Skripsi, Program Studi Kesehatan Masyarakat, Fakultas Kedokteran dan IImu Kesehatan, UIN Syarif Hidayatullah Jakarta, Jakarta. 
2. Alom, M. (2011). Marketing: an Islamic perspective. World Journal of Soc. Sc., 1(3), 7181.

3. Assael, Henry. 2002. Consumer Behavior and Marketing Action. Fifth Edition. Cincinnati Ohio: South-Western College Publishing.

4. Azzadina, Irna and Huda, Aulia Nurul, (2012), Corinthias Pamatang Morgana Sianipar Understanding Relationship between Personality Types, Marketing-mix Factors, and Purchasing Decisions, Procedia - Social and Behavioral Sciences 65, 352 - 357.

5. Budiyoanto, Ary (2015), Consuming Islamic Images. The politics of contemporary Indonesian Islamic Culture Industry, Universitas Gadja Mada, Yogyakarta, Indonesia.

6. Cortez, N (2008), Patient without Borders: The Emerging Global Market for Patients and the Evolution of Modern Health Care. Indiana Law Journal, 83:7.

7. Henama, Unathi Sonwabile (2014), "Health tourism in South Africa: opportunities and possibilities" African Journal of Hospitality, Tourism and Leisure Vol. 3 (1), pp. 1-8.

8. Herrick, Devon (2007), "Medical Tourism: Global Competition in Health Care", NCPA Policy Report No. 304, National Center for Policy Analysis: Dallas, Texas.

9. Kotler, Philip (2009). Manajemen Pemasaran. Alih Bahasa: Jaka Wasana. Jakarta: Penerbit Airlangga.

10. Kotler, Philip dan Keller, K.L. (2006). Manajemen Pemasaran. Alih Bahasa Benyamin Molan, Ed. 12, Jilid 2. Jakarta: Penerbit PT Indeks.

11. Kotler, P. (2001). Prinsip-Prinsip Pemasaran, Alih Bahasa Imam Nurmawan, Jakarta.

12. Kusjuniardi, Mutiara Yudinda (2014), Salon Khusus Wanita Muslimah dengan Interior yang Bernuansakan Timur Tengah, Studi Kasus: Salon Moz5 Surabaya, Skripsi, Jurusan Desain Produk Industri, FTSP, Institut Teknologi Surabaya, Surabaya.

13. Lovelock, C., Wirtz, J (2011). 2nd Edition. Essentials of Services Marketing. Singapore: Prentice Hall. Marketing, Vol. 3, pp. 212-216.

14. MacReady, N (2007), Developing countries court medical tourists. Lancet, 369:18491850.

15. Munro, Julie W (2012) "Best Practices in Medical Tourism \#3: What is Medical Tourism?", Medical Travel Quality Assurance (MTQUA), Bangkok, Thailand.

16. Narendran, R. (2011). Are the female entrepreneurs of beauty salons in India, victims of bad publicity?. Int. J. of Diver. in Organizations, Communities and Nations, 11 (1), 47-56.

17. Payne, Adrian. 2001. The Essence of Service Marketing. Diterjemahkan oleh: Fandy Ciptono. Penerbit Andi. Yogyakarta.

18. Pendit, I Nyoman, S. 1994. Ilmu Pariwisata Sebuah Pengantar Perdana. Jakarta: Pradnya Paramita. Sari, Dian Permata (2013) Standar Kinerja Karyawan Azzahra Salon dan Spa Muslimah Yogyakarta, Skripsi, Fakultas Dakwah, Universitas Islam Negeri Sunan Kalijaga Yogyakarta.

19. Schiffman. G, Leon, Leslie, Lazar, Kanuk (2008). Perilaku Konsumen. Alih Bahasa Zoelkifli Kasip. Jakarta: Gramedia.

20. Tilaar, Martha (2011), Pioneers in Science, Jakarta: Dian Rakyat.

21. Trison, Sonia Yulia (2015), Bogor Az-Zikra Sharia Beauty Care and Fitness Center, Publikasi Ilmiah, Program Studi Arsitektur Fakultas Teknik, Universitas Muhammadiyah Surakarta.

22. Vahdati, Hojjat, Najmeddin Mousavi, Javad Taheri Moghadam (2014), A Study on the Effect of Marketing Mix on the Repurchase Intention with the Consideration of the Mediating Role of Brand Equity (Case Study: Ghaem Shahr Refah Bank), Advances in Environmental Biology, 8(21) October, Pages: 467-474.

23. Yaman, Rostam; Zarina Alias and Norishahaini Mohamed Ishak (2012) "Beauty Treatment and Spa Design from Islamic Perspective", Procedia - Social and Behavioral Sciences 50 (2012) $492-501$.

24. Young, G. (1973). Tourism - Blessing or Blight?. London: Penguin.

(C) 2017 by the authors. Licensee RJOAS, Orel, Russia. This article is an open access article distributed under the terms and conditions of the Creative Commons Attribution (CC BY) license: http://creativecommons.org/licenses/by/4.0/ 